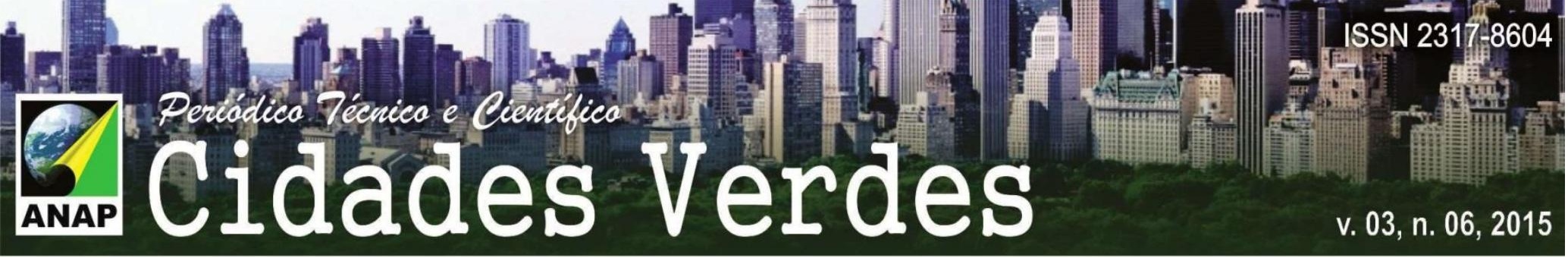

Titulo do Trabalho

\title{
INFRAESTRUTURA VERDE COMO INSTRUMENTO DE LEGISLAÇÃO URBANA: UMA ANÁLISE DO PLANO DIRETOR ESTRATÉGICO DE SÃO PAULO.
}

Nome do Autor (a) Principal

Evy Hannes

Instituição ou Empresa

Universidade Paulista UNIP

Instituição (s) de Fomento

Universidade Presbiteriana Mackenzie

E-mail de contato

evyhannes@yahoo.com; evyhannes@gmail.com

Palavras-chave

Infraestrutura Verde, Legislação Urbana, Plano Diretor Estratégico de São Paulo.

\section{INTRODUÇÃO}

Nas ultimas décadas, a população mundial está cada vez mais consciente da magnitude dos problemas ambientais que nosso planeta enfrenta. Já que o Planeta Terra é um sistema de organismos que funcionam como um todo único e o desequilíbrio ecológico de uma região gera efeitos colaterais devastadores, em outra, mesmo que do outro lado do planeta, é necessário criar uma conscientização sobre a importância do pensamento ecossistêmico (FRANCO, 2000). Por isso é fundamental que a dinâmica das cidades seja alterada e que os processos de transformação do território sejam fundamentados em princípios ambientais e 


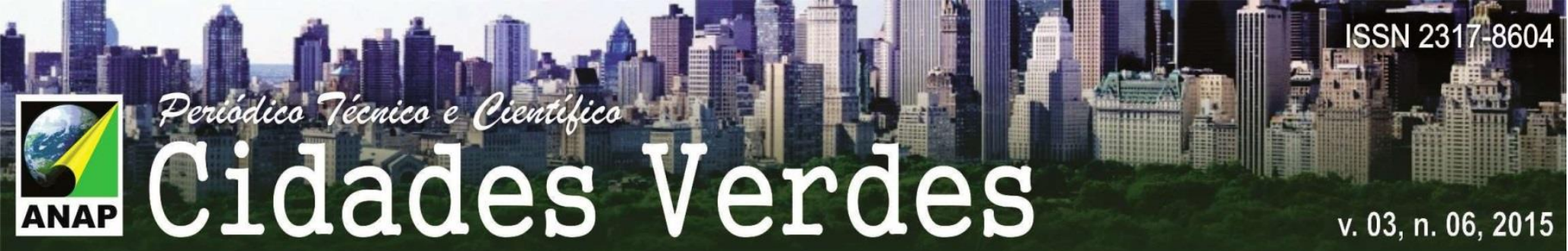

ecológicos, respeitando a lógica dos ecossistemas que os compõe, através de um novo sistema de projetar que busque soluções inovadoras e sustentáveis e que se apoie em conceitos baseados no desenho ambiental e ecologia da paisagem.

\subsection{OBJETIVOS}

O objetivo desse trabalho é, além de desenvolver breve conceituação teórica referente ao conceito de infraestrutura verde, investigar a possibilidade de aplicação dos conceitos relativos à esse tema no processo de planejamento e remodelagem das cidades contemporâneas, através da transformação dos mesmos em instrumentos de legislação urbanística.

\subsection{METODOLOGIA}

A metodologia utilizada parte da análise sistêmica ${ }^{1}$ e holística ${ }^{2}$ do conceito de infraestrutura verde, analisando algumas das principais obras publicadas sobre essa temática. Na sequência, é analisado o caso específico do Plano Diretor de São Paulo em busca de elementos que possam configurar ou vincular o desenvolvimento de uma rede de infraestrutura verde na cidade de São Paulo.

\section{RESULTADOS}

No século XIX, com o grande crescimento das cidades e seu consequente impacto no ambiente urbano, o espaço verde foi pela primeira vez introduzido nas cidades como elemento mitigador desses danos. Como exemplos desse tipo de intervenção podemos citar o Sistema de Parques de Boston projetado por Frederick Law Olmsted e as "Cidades- Jardim" de Ebenezer Howard. Esses projetos já demonstravam a preocupação com a conservação e incorporação de áreas verdes

\footnotetext{
${ }^{1}$ Utilizaremos nesse estudo o conceito de sistemas defendido por Odum que é caracterizado por um conjunto de elementos naturais que se relacionam e realizam de troca de energia.

${ }^{2}$ Esse estudo utiliza o conceito de holos derivado da ecologia, que entende o planeta como um todo, um elemento único do qual as partes não funcionam separadamente.
} 
amigável.(...) No entanto infraestrutura verde pode ter um significado mais ambicioso e abrangente. (BENEDICT; MCMAHON, 2006).

Podemos então dizer que infraestrutura verde é uma rede de conexões que funciona na forma de sistema, considerando os elementos naturais ou projetados e que visa o equilíbrio e a conservação dos processos da paisagem, promovendo benefícios econômicos, culturais e sociais. São projetos de baixo impacto e alto desempenho e deverão ser o suporte dos ecossistemas da paisagem urbana, provedores de biodiversidade e fornecedores de abrigo para fauna e flora, exercendo múltiplas funções na sociedade . (HERZOG, 2010)

Ainda segundo Herzog (2010), se bem planejada, a infraestrutura verde pode funcinar como suporte para a resiliência das cidades. Por resiliência urbana podemos entender a capacidade de resposta e recuperação do meio urbano aos danos causados pela urbanização excessiva, eventos climáticos e degradação de recursos naturais. É a forma que o meio ambiente tem de se recuperar após ser perturbado.

O Plano Diretor Estratégico de São Paulo (PDE), Lei oํ 16.050/2014, aborda a questão do meio ambiente com o seguinte título: "Incorporar a agenda ambiental ao desenvolvimento da cidade". Trata o tema como um conjunto de cinco macro ações sendo elas: demarcação da zona rural com concepção multifuncional, criação de 167 novos parques, criação do fundo municipal de parques, pagamento por prestação de serviços ambientais (PSA) e políticas setoriais de gestão ambiental. Esse estudo pretende abordar apenas os itens que podem ter desenvolvimento em questões relacionadas ao projeto da cidade e possível implantação de um sistema de infraestrutura verde e portanto será deixado de lado, mesmo sabendo de sua importância na construção de processos assertivos, questões relacionadas ao recolhimento de fundos e mecanismos de financiamento. Dessa forma, serão analisados dois itens propostos no plano: a proposição de 167 parques e a demarcação da zona rural.

O PDE propõe, como uma de suas metas ambientais, a criação de 167 novos parques e a transformação desses novos espaços em ZEPAM (zonas especiais de proteção ambiental). A princípio, esse número pode até parecer bem 
